\title{
Analisa Faktor-Faktor yang Mempengaruhi Keputusan Nasabah Menggunakan Produk Perbankan (Studi Kasus Nasabah Bank Syariah Indonesia Kantor Cabang Pembantu Muara Bulian)
}

\author{
Sumantri ${ }^{1 *}$, Diyah $^{2}$, Albetris $^{3}$ \\ ${ }^{1,2}$ STIE Graha Karya Muara Bulian \\ ${ }^{3}$ Universitas Batanghari Jambi \\ *Correspondence email: sumantri.baharun123@gmail.com, albetris90@gmail.com
}

\begin{abstract}
Abstrak. Penelitian ini bertujuan untuk mengetahui pengaruh pelayanan, karakteristik bank, pengetahuan, lokasi terhadap keputusan nasabah menggunakan Bank Syariah Indonesia (Studi Kasus Kantor Cabang Pusat Muara Bulian). Penelitian ini menggunakan teknik sampling dengan sampel 100 nasabah Bank Syariah Indonesia Kantor Cabang Pembantu Muara Bulian. Metode penelitian ini adalah menggunakan metode penelitian kualitatif dengan bantuan aplikasi SPSS sebagai alat hitung data yang telah di dapat. Penelitian ini menggunakan 4 variabel yaitu pelayanan, karakteristik bank, pengetahuan, lokasi. Hasil dari penelitian ini menunjukan bahwa secara parsial Karakteristik Bank sangat pengaruh terhadap keputusan nasabah sebesar 4.87, dan menjadi faktor yang paling dominan, Pelayanan berpengaruh terhadap keputusan nasabah sebesar 4.11, Pengetahuan cukup pengaruh terhadap keputusan nasabah sebesar 3.4, dan Lokasi berpengaruh terhadap keputusan nasabah sebesar 3.9.
\end{abstract}

Kata Kunci: Pelayanan; Karakteristik Bank; Pengetahuan; Lokasi; Keputusan menggunakan produk

Abstract. This research aims to determine the influence of services, bank characteristics, knowledge, location on customer decisions using Bank Syariah Indonesia (Case Study of Muara Bulian Central Branch Office). This study used sampling techniques with a sample of 100 customers of Bank Syariah Indonesia Muara Bulian Sub-Branch Office. This research method is to use qualitative research method with the help of SPSS application as a data calculation tool that has been able to. This study uses 4 variables, namely service, bank characteristics, knowledge, location. The results of this study show that partially the Characteristics of the Bank are very influential to customer decisions by 4.87, and become the most dominant factor, the Service affects customer decisions by 4.11, Knowledge is quite influential on customer decisions by 3.4, and Location affects customer decisions by 3.9 .

Keywords: Service; Characteristics of the Bank; Knowledge; Location; Decisions on using the product

\section{PENDAHULUAN}

Bank Syariah adalah bank umum, sebagaimana tertuang dalam Undang-Undang Nomor 7 Tahun 1992 tentang Perbankan, kini telah diubah dengan UndangUndang Nomor 10 Tahun 1998, yang melakukan kegiatan usaha sesuai dengan prinsip-prinsip hukum Syariah, termasuk hukum Islam. Unit bisnis Prancis dan cabang bank asing. Menjalankan kegiatan usaha sesuai dengan prinsip-prinsip hukum Syariah.

Contohnya jika pada bank tradisional istilah "bunga bank" digunakan pada bank umum untuk menyatakan keuntungan, maka pada bank syariah keuntungan yang diperoleh nasabah disebut "bagi hasil" atau mudharabah dalam hukum Islam.

Menurut Syafi'i Antonio (2001), perbankan syariah adalah sistem perbankan yang pelaksanaannya berdasarkan syariat Islam. Pembentukan sistem didasarkan pada larangan Islam meminjamkan atau menerima pinjaman melalui pengumpulan bunga pinjaman (riba), dan larangan investasi di perusahaan yang diklasifikasikan sebagai dilarang (haram).

Menurut drummond (2007) keputusan nasabah ialah mengenali opsi yang bisa jadi buat membongkar perkara itu, serta memperhitungkan pilihan-pilihan secara sistematis. Keputusan pula wajib menaggapi pertanyaan, tentang apa yang wajib dicoba serta apa yang harus dibicarakan dalam hubungan nya dengan perencanaan. (Asmas dan Adisetiawan, 2019)

Keputusan yang terbuat memakai sesuatu produk atapun jasa oleh nasabah timbul dari faktor-faktor tertentu, tipe bahan-bahan yang bermacam-macam di bank pula ikut pengaruhi keputusan nasabah memakai produk bank.

Bermacam kecenderungan sebagian konsep dari hasil riset mengenali pertumbuhan bank syariah serta banyaknya aspek-aspek yang pengaruhi nasabah memakai produk perbankan syariah.

Bank syariah di muara tembesi banyak diminati oleh masyarakat, ada tahun 2020 jumlah nasabah berjumlah 1000. Pengguna produk perbankan syariah memiliki harapan bisa dilayani oleh bank yang sesuai syariah. Oleh karena itu bank syariah banyak diminati oleh masyarakat atas pemakaian produknya. Mereka bisa memandang dengan gampang perbandingan yang signifikan antara produk perbankan syariah dengan bank konvemsional. Baik bank syariah maupun bank 
konvensional menawarkan begitu banyak sarana pelayanan, serta produk yang sangat memanjakan para nasabahnya.

Fenomena yang terjadi pada penelitian ini merupakan mayoritas masyarakat di batang hari beragama islam dan menurut syariat islam dalam urusan suku bunga pinjam meminjam sudah memiliki ketentuan tertentu yg telah di tetapkan, sedangkan beberapa bank yang ada di daerah muara tembesi masih belum mengikuti aturan tersebut.

Penelitian sebelumnya menjelaskan tentang faktor-faktor yang mempengaruhi minat menabung masyarakat di Bank Syari'ah (Studi Kasus Nasabah Bank Syari'ah Indonesia Cabang Gorontalo) yang disusun oleh Mohammad Zubair Hippy (2014), penelitian ini bertujuan untuk menguji pengaruh pelayanan, pengetahuan, produk, dan promosi terhadap minat menabung masyarakat di Bank Syari'ah cabang medan. Sampel dalam penelitian ini adalah 150 orang.

Kesimpulan hasil riset ini membuktikan bahwa nilai t-hitung untuk variabel pelayanan 0,881 sebaliknya t-tabel nya 1,984 . Perihal ini jauh lebih kecil dari pada thitung. Maksudnya variabel pelayanan mempengaruhi positif tetapi tidak signifikan terhadap atensi menabung. Variabel pengetahuan masyarakat didapat t-hitung sebesar 2,435>1,984 ialah t-hitung lebih besar dari pada t-tabel. Maksudnya variabel pengetahuan masyarakat mempengaruhi positif serta signifikan terhadap atensi menabung. T-hitung untuk variabel produk bank syariah didapatkan hasil 2,900 sehingga thitung jauh lebih besar dari nilai t-tabel mempengaruhi positif serta signifikan terhadap atensi menabung.

Serta t-hitung promosi didapat 4,673 nilai ini pula lebih besar dari t-tabel sehingga bisa disimpulkan variabel promosi mempengaruhi positif serta signifikan terhadap atensi menabung. Secara simultan pelayanan, pengetahuan, produk serta promosi diperoleh dari nilai koefeisien determinasi sebesar 0,571. Nilai ini berarti jika sebesar $57,1 \%$ atensi menabung di bank syariah cabang gorontalo mempengaruhi signifikan terhadap atensi menabung dankeahlian variabel-variabel leluasa dalam menerangkan variabel yang cukup baik.

Adapun persamaan yang mendasar dalam penelitian sekarang dengan penelitian terdahulu ialah sama-sama meneliti tentang pengetahuan dan kualitas pelayanan, tetapi yang menjadi perbedaan penelitian sebelumnya dengan penelitian yang penulis lakukan adalah peneliti menambahkan dua variabel bebas lainnya yaitu karakteristik bank, lokasi.

Penelitian ini meneliti tentang prilaku nasabah Bank Syari'ah Indonesia Kcp Muara Bulian dalam memutuskan menggunakan Produk Bank. Dengan memilih, mengatur, dan menginterpretasikan hal-hal terkait Bank, nasabah akan dapat merasakan bahwa mereka merasa puas atau tidak terhadap produk perbankan tersebut. Jika mereka merasa puas, maka mereka akan memilih untuk menggunakan produk perbankan ini dimasa depan, begitu juga sebaliknya. oleh karena itu, perilaku pengguna perbankan tepat untuk meneliti faktor keputusan pada diri nasabah.

\section{METODE}

Tipe Riset, Bagi Bambang Sunggono (2005) Tata cara riset yang di pakai dalam riset ini merupakan tata cara riset lapangan. Riset lapangan ataupun tata cara field reseach yang di iktikad merupakan riset yang dicoba dengan menghadiri industri serta tempat yang lain (Ahmadi dan Adisetiawan, 2020)

Jenis Penelitian, Menurut Bambang Sunggono (2005) Metode penelitian yang di gunakan dalam penelitian ini adalah metode penelitian lapangan. Penelitian lapangan atau metode field reseach yang di maksud adalah penelitian yang dilakukan dengan mendatangi perusahaan dan tempat lainnya.

Jenis Data, Penelitian ini menggunakan metode penelitian kualitatif. Data kualitatif, Bog dan dan Taylor (dalam Moleong, 2011) mendefinisikan kualitatif sebagai cara yang digumakan dalam penelitian untuk menghasilkan data yang deskriptif.

Sumber Data Sumber data dalam penelitian ini menyangkut kualitas dari hasil penelitian, data primer dan sekunder yang diperoleh.

Metode Pengumpulan Data, Agar penelitian ini menjadi relevan dan mengandung kebenaran yang objektif, maka penulis menggunakan metode pengumpulan data sebagai berikut :

Riset Perputakaan Yaitu penulis memperoleh informasi dan masukan-masukan dari kerangka teoritis mengenai faktor dominan yang mempengaruhi keputusan nasabah serta pembahasannya dari buku-buku ilmu pengetahuan yang berkaitan dengan pokok permasalahan.

Riset lapangan, Dengan melakukan riset lapangan, penulis memperoleh data langsung dari objek yang dituju dengan cara :

Observasi, Yaitu suatu teknik pengumpulan data dengan jalan mengamati dan terjun langsung ke lapangan, melihat secara nyata keadaan dan kondisi perusahaan dengan segala aspek kegiatan yang berhubungan dengan penelitian. Interview atau wawancara, dan Kuesioner.

Populasi, Populasi merupakan kumpulan data yang sama dalam hal tertentu, sehingga terbentuk masalah (Tjiptono, 2002). Adapun populasi dalam penelitian ini adalah jumlah nasabah Bank Syariah Indonesia Kcp Muara Bulian tahun 2020 yaitu sebanyak 1.000 nasabah.

Sampel, Sampel adalah bagian dari yang hendak di teliti dan mewakili karakteristik populasi. Menurut Arikunto (2000) apabila populasi penelitian berjumlah kurang dari 100 orang maka sampel yang di ambil adalah semuanya. Namun apabila populasi penelitian berjumlah lebih dari 100 maka sampel yang di ambil 10$15 \%$ atau $20-25 \%$ atau lebih. 
Sumantri, Diyah dan Albetris, Analisa Faktor-Faktor yang Mempengaruhi Keputusan Nasabah Menggunakan Produk Perbankan (Studi Kasus Nasabah Bank Syariah Indonesia Kantor Cabang Pembantu Muara Bulian)

Jumlah nasabah BSM pada tahun 2020 berjumlah 1.000 nasabah, karena keterbatasannya kesempatan untuk memperoleh sampel lebih banyak karena pandemi Covid-19 maka peneliti mengambil sampel sebanyak $10 \%$ dari populasi. jumlah nasabah BSI kantor cabang Muara Bulian sebanyak 1.000 x 10\%, maka di hasilkan sampel 100 nasabah.

Rumus yang di gunakan untuk pengambilan sampel adalah :

$\mathrm{n}=10 \% \times \mathrm{N}$

dimana: $\mathrm{n}=$ Besar sampel; $\mathrm{N}=$ Besar Populasi (Nasabah).

Alat Analisa, Skala Likert, Menurut Sugiyono (2011) Skala Likert umtuk mengukur sikap dalam fenomena sosial sesuai data yang dibutuhkan, skala likert yang mempunyai 5 tingkatan yaitu:

1. Sangat Tidak Pengaruh $=($ Skor 1$)$

2. Tidak Pengaruh $=($ Skor 2$)$

3. Cukup Pengaruh $=($ Skor 3$)$

4. Pengaruh $=($ Skor 4$)$

5. Sangat Pengaruh $=($ Skor 5$)$

Menurut Husein Umar (2001) alat analisa dilakukan dengan menggunakan nilai indeks yaitu dengan menentukan nilai besarnya kelas sebagai berikut

Nilai Maksimum : 5

Nilai Minimum : 1

Rentang Skala $=\frac{\text { (nilai maksimum-nilai minimum) }}{\text { jumlah } \text { indeks }}$

$$
\begin{aligned}
& =\frac{(5-1)}{5} \\
& =0,8
\end{aligned}
$$

Jadi tabel indeks penilaian adalah sebagai berikut :

Tabel 1. Indeks Penilaian Pelayanan, Karakteristik Bank,

$$
\text { Pengetahuan, Lokasi. }
$$

\begin{tabular}{cc}
\hline Nilai Indeks & Penilaian \\
\hline $1 \leq x \leq 1,80$ & Sangat Tidak Pengaruh \\
$1,80<\mathrm{x} \leq 2,60$ & Tidak Pengaruh \\
$2,60<\mathrm{x} \leq 3,40$ & Cukup Pengaruh \\
$3,40<\mathrm{x} \leq 4,20$ & Pengaruh \\
$4,20<\mathrm{x} \leq 5,0$ & Sangat Pengaruh \\
\hline
\end{tabular}

\section{HASIL DAN PEMBAHASAN \\ Tanggapan Nasabah Terhadap Faktor-Faktor Yang Mempengaruhi Keputusan Nasabah Menggunakanj Produk Bank Syariah Indonesia Kantor Cabang Muara Bulian. \\ Faktor Pelayanan}

Berdasarkan data dari SPSS.20, hasil yang di dapatkan yaitu Valid, karena sesuai dengan jumlah kuesioner yang telah disebar kepada nasabah Bank Syariah Indonesia Kantor Cabang Pembantu Muara Bulian. Dapat dilihat dalam tabel berikut:

Tabel 2. Data Kuesioner Nasabah Terhadap Faktor Pelayanan, SPSS. 20

\begin{tabular}{|l|l|l|l|l|l|}
\hline Statistics & x.1.p1 & x.1.p2 & x.1.p3 & x.1.p3 & x.1.p4 \\
\hline Valid & 100 & 100 & 100 & 100 & 100 \\
Missing & 0 & 0 & 0 & 0 & 0 \\
\hline
\end{tabular}

\begin{tabular}{|l|l|l|l|l|}
\hline $\begin{array}{l}\text { Valid } \\
\text { x.1.p1 }\end{array}$ & Frequency & Percent & $\begin{array}{l}\text { Valid } \\
\text { Percent }\end{array}$ & $\begin{array}{l}\text { Comulative } \\
\text { Percent }\end{array}$ \\
\hline P & 70 & 70 & 70 & 70 \\
SP & 30 & 30 & 30 & 100 \\
\cline { 1 - 4 } Total & 100 & 100 & 100 & \\
\hline
\end{tabular}

\begin{tabular}{|l|l|l|l|l|}
\hline $\begin{array}{l}\text { Valid } \\
\text { x.1.p2 }\end{array}$ & Frequency & Percent & $\begin{array}{l}\text { Valid } \\
\text { Percent }\end{array}$ & $\begin{array}{l}\text { Comulative } \\
\text { Percent }\end{array}$ \\
\hline P & 76 & 76 & 76 & 76 \\
SP & 24 & 24 & 24 & 100 \\
\hline Total & 100 & 100 & 100 & \\
\hline
\end{tabular}

\begin{tabular}{|l|l|l|l|l|}
\hline $\begin{array}{l}\text { Valid } \\
\text { x.1.p3 }\end{array}$ & Frequency & Percent & $\begin{array}{l}\text { Valid } \\
\text { Percent }\end{array}$ & $\begin{array}{l}\text { Comulative } \\
\text { Percent }\end{array}$ \\
\hline CP & 49 & 49 & 49 & 49 \\
P & 5 & 5 & 5 & 54 \\
SP & 46 & 46 & 46 & 100 \\
\cline { 1 - 3 } Total & 100 & 100 & 100 & \\
\hline
\end{tabular}

\begin{tabular}{|l|l|l|l|l|}
\hline $\begin{array}{l}\text { Valid } \\
\text { x.1.p4 }\end{array}$ & Frequency & Percent & $\begin{array}{l}\text { Valid } \\
\text { Percent }\end{array}$ & $\begin{array}{l}\text { Comulative } \\
\text { Percent }\end{array}$ \\
\hline CP & 89 & 89 & 89 & 89 \\
SP & 11 & 11 & 11 & 100 \\
\hline Total & 100 & 100 & 100 & \\
\hline
\end{tabular}

\begin{tabular}{|l|l|l|l|l|}
\hline $\begin{array}{l}\text { Valid } \\
\text { x.1.p5 }\end{array}$ & Frequency & Percent & $\begin{array}{l}\text { Valid } \\
\text { Percent }\end{array}$ & $\begin{array}{l}\text { Comulative } \\
\text { Percent }\end{array}$ \\
\hline P & 18 & 18 & 18 & 18 \\
SP & 82 & 82 & 82 & 100 \\
\hline Total & 100 & 100 & 100 & \\
\hline
\end{tabular}

Gambaran mengenai kondisi Pelayanan yang mempengaruhi keputusan nasabah menggunakan Produk Bank Syariah Indonesia Kantor Cabang Muara Bulian, dimana faktor tersebut dapat menimbulkan pengaruh bagi nasabah dalam memilih Bank Syariah Indonesia Kantor Cabang Muara Bulian dari pada Bank Konvensional lainnya.

Dimana hasil yang didapat sangat sesuai dengan yang ada dilapangan. Ini dapat dilihat dari hasil kegiatan penelitian berupa penyebaran kuisioner sebagaimana dalam tabel berikut: 
Sumantri, Diyah dan Albetris, Analisa Faktor-Faktor yang Mempengaruhi Keputusan Nasabah Menggunakan Produk Perbankan (Studi Kasus Nasabah Bank Syariah Indonesia Kantor Cabang Pembantu Muara Bulian)

Tabel 3. Rekapitulasi Data Tangggapan Responden Terhadap Faktor Pelayanan

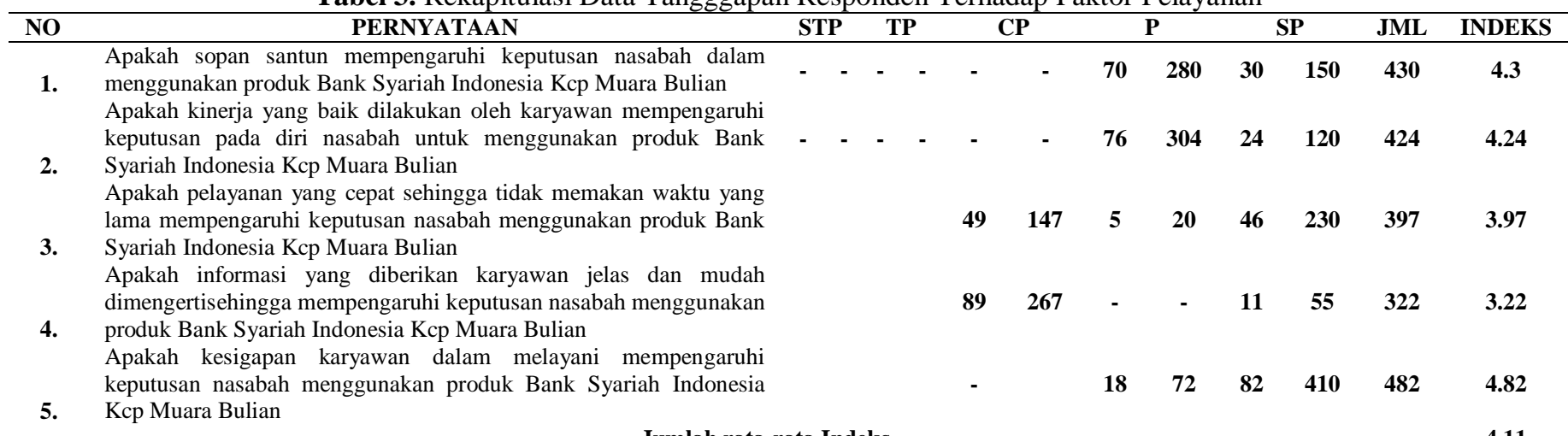

Jumlah rata-rata Indeks

Sumber: Nasabah Bank Syariah Indonesia Kcp Muara Bulian (data diolah menggunakan IBM spss 20)

Berdasarkan tabel 3 dapat diketahui hasil pengolahan dengan presentase dari lima aspek penilaian yang dinyatakan dalam tabel menunjukan hasil tertinggi adalah 4.82 , yang terendah 4.3 , dan rata-rata indeks dari 5 peryataan diatas adalah 4.11 .

Berdasarkan dari hasil rata-rata indeks tabel di atas membuktikan bahwa faktor keputusan nasabah (pelayanan) pada Bank Syariah Indonesia Kantor Cabang Pembantu Muara Bulian berada pada kategori Baik.

\section{Faktor Karakteristik Bank}

Berdasarkan data dari SPSS.20, hasil yang di dapatkan yaitu Valid, karena sesuai dengan jumlah kuesioner yang telah disebar kepada nasabah Bank Syariah Indonesia Kantor Cabang Pembantu Muara Bulian. Dapat dilihat dalam tabel berikut:

Tabel 4. Data Kuesioner Nasabah Terhadap Faktor Karakteristik Bank, SPSS.20

\begin{tabular}{|l|l|l|l|l|l|}
\hline Statistics & x.2.p1 & x.2.p2 & x.2.p3 & x.2.p3 & x.2.p4 \\
\hline Valid & 100 & 100 & 100 & 100 & 100 \\
Missing & 0 & 0 & 0 & 0 & 0 \\
\hline
\end{tabular}

\begin{tabular}{|l|l|l|l|l|}
\hline $\begin{array}{l}\text { Valid } \\
\text { x.2.p1 }\end{array}$ & Frequency & Percent & $\begin{array}{l}\text { Valid } \\
\text { Percent }\end{array}$ & $\begin{array}{l}\text { Comulative } \\
\text { Percent }\end{array}$ \\
\hline P & 11 & 11 & 11 & 11 \\
SP & 89 & 89 & 89 & 100 \\
\hline Total & 100 & 100 & 100 & \\
\hline
\end{tabular}

\begin{tabular}{|l|l|l|l|l|}
\hline $\begin{array}{l}\text { Valid } \\
\text { x.2.p2 }\end{array}$ & Frequency & Percent & $\begin{array}{l}\text { Valid } \\
\text { Percent }\end{array}$ & $\begin{array}{l}\text { Comulative } \\
\text { Percent }\end{array}$ \\
\hline P & 18 & 18 & 18 & 18 \\
\hline
\end{tabular}

\begin{tabular}{|l|l|l|l|l|}
\hline SP & 82 & 82 & 82 & \multirow{2}{*}{100} \\
\cline { 1 - 4 } Total & 100 & 100 & 100 & \\
\hline
\end{tabular}

\begin{tabular}{|l|l|l|l|l|}
\hline $\begin{array}{l}\text { Valid } \\
\text { x.2.p3 }\end{array}$ & Frequency & Percent & $\begin{array}{l}\text { Valid } \\
\text { Percent }\end{array}$ & $\begin{array}{l}\text { Comulative } \\
\text { Percent }\end{array}$ \\
\hline P & 15 & 15 & 15 & 15 \\
SP & 85 & 85 & 85 & 100 \\
\hline Total & 100 & 100 & 100 & \\
\hline
\end{tabular}

\begin{tabular}{|l|l|l|l|l|}
\hline $\begin{array}{l}\text { Valid } \\
\text { x.2.p4 }\end{array}$ & Frequency & Percent & $\begin{array}{l}\text { Valid } \\
\text { Percent }\end{array}$ & $\begin{array}{l}\text { Comulative } \\
\text { Percent }\end{array}$ \\
\hline P & 11 & 11 & 11 & 11 \\
SP & 89 & 89 & 89 & 100 \\
\hline Total & 100 & 100 & 100 & \\
\hline
\end{tabular}

\begin{tabular}{|l|l|l|l|l|}
\hline $\begin{array}{l}\text { Valid } \\
\text { x.2.p5 }\end{array}$ & Frequency & Percent & $\begin{array}{l}\text { Valid } \\
\text { Percent }\end{array}$ & $\begin{array}{l}\text { Comulative } \\
\text { Percent }\end{array}$ \\
\hline P & 12 & 12 & 12 & 12 \\
SP & 88 & 88 & 88 & 100 \\
\hline Total & 100 & 100 & 100 & \\
\hline
\end{tabular}

Gambaran mengenai kondisi Karakteristik Bank yang mempengaruhi keputusan nasabah menggunakan Produk Bank Syariah Indonesia Kantor Cabang Muara Bulian, dimana faktor tersebut dapat menimbulkan pengaruh bagi nasabah dalam memilih Bank Syariah Indonesia Kantor Cabang Muara Bulian dari pada Bank Konvensional lainnya.

Dimana hasil yang didapat sangat sesuai dengan yang ada dilapangan. Ini dapat dilihat dari hasil kegiatan penelitian berupa penyebaran kuisioner sebagaimana dalam tabel berikut:

Tabel 5. Rekapitulasi Dan Tangggapan Responden Terhadap Faktor Karakteristik Bank

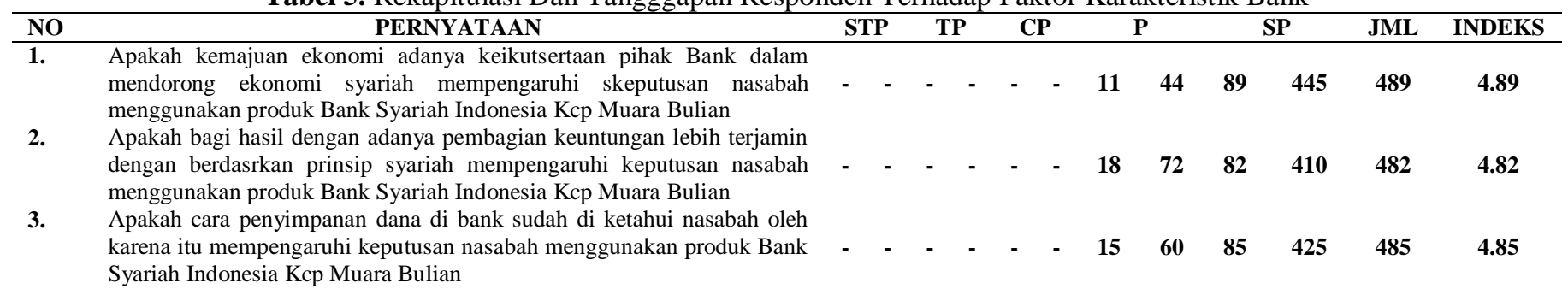


Sumantri, Diyah dan Albetris, Analisa Faktor-Faktor yang Mempengaruhi Keputusan Nasabah Menggunakan Produk Perbankan (Studi Kasus Nasabah Bank Syariah Indonesia Kantor Cabang Pembantu Muara Bulian)

4. Apakah pengetahuan tentang produk mempengaruhi keputusan nasabah menggunakan produk Bank Syariah Indonesia Kcp Muara Bulian

5 Apakah bebas riba dalam suatu bank menjadikan nasabah

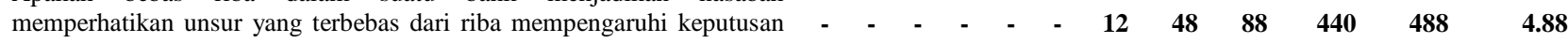
nasabah menggunakan Bank Syariah Indonesia Kcp Muara Bulian

Jumlah rata-rata Indeks

Sumber: Nasabah Bank Syariah Indonesia Kcp Muara Bulian(data diolah menggunakan IBM spss 20)

Berdasarkan tabel 5 diketahui dari pengolahan dengan presentase dari lima aspek penilaian yang dinyatakan dalam tabel menunjukan hasil tertinggi adalah 4.89 , yang terendah 2.88 dan rata-rata indeks dari 5 pernyataan di atas adalah 4.87 .

Berdasarkan dari hasil rata-rata indeks tabel di atas membuktikan bahwa faktor keputusan nasabah (karakteristik bank) pada Bank Syariah Indonesia Kantor Cabang Pembantu Muara Bulian berada pada kategori Sangat Baik.

\section{Faktor Pengetahuan}

Berdasarkan data dari SPSS.20, hasil yang di dapatkan yaitu Valid, karena sesuai dengan jumlah kuesioner yang telah disebar kepada nasabah Bank Syariah Indonesia Kantor Cabang Pembantu Muara Bulian. Dapat dilihat dalam tabel berikut:

Tabel 6. Data Kuesioner Nasabah Terhadap Faktor Pengetahuan, SPSS.20

\begin{tabular}{|l|l|l|l|l|l|}
\hline Statistics & x.3.p1 & x.3.p2 & x.3.p3 & x.3.p3 & x.3.p4 \\
\hline Valid & 100 & 100 & 100 & 100 & 100 \\
Missing & 0 & 0 & 0 & 0 & 0 \\
\hline
\end{tabular}

\begin{tabular}{|l|l|l|l|l|}
\hline $\begin{array}{l}\text { Valid } \\
\text { x.3.p1 }\end{array}$ & Frequency & Percent & $\begin{array}{l}\text { Valid } \\
\text { Percent }\end{array}$ & $\begin{array}{l}\text { Comulative } \\
\text { Percent }\end{array}$ \\
\cline { 1 - 3 } CP & 77 & 77 & 7 & 77 \\
P & 2 & 2 & 2 & 79 \\
SP & 21 & 21 & 21 & 100 \\
\cline { 1 - 3 } Total & 100 & 100 & 100 & \\
\hline
\end{tabular}

\begin{tabular}{|l|l|l|l|l|}
\hline $\begin{array}{l}\text { Valid } \\
\text { x.3.p2 }\end{array}$ & Frequency & Percent & $\begin{array}{l}\text { Valid } \\
\text { Percent }\end{array}$ & $\begin{array}{l}\text { Comulative } \\
\text { Percent }\end{array}$ \\
\hline $\mathrm{CP}$ & 77 & 77 & 77 & 77 \\
$\mathrm{P}$ & 10 & 10 & 10 & 87 \\
\hline
\end{tabular}

\begin{tabular}{|c|c|c|c|c|}
\hline SP & 13 & 13 & 13 & \multirow[t]{2}{*}{100} \\
\hline Total & 100 & 100 & 100 & \\
\hline $\begin{array}{l}\text { Valid } \\
\text { x.3.p3 }\end{array}$ & Frequency & Percent & $\begin{array}{l}\text { Valid } \\
\text { Percent }\end{array}$ & $\begin{array}{l}\text { Comulative } \\
\text { Percent }\end{array}$ \\
\hline $\mathrm{CP}$ & 73 & 73 & 73 & \multirow{4}{*}{$\begin{array}{l}73 \\
82 \\
100\end{array}$} \\
\hline $\mathrm{P}$ & 9 & 9 & 9 & \\
\hline SP & 18 & 18 & 18 & \\
\hline Total & 100 & 100 & 100 & \\
\hline
\end{tabular}

\begin{tabular}{|l|l|l|l|l|}
\hline $\begin{array}{l}\text { Valid } \\
\text { x.3.p4 }\end{array}$ & Frequency & Percent & $\begin{array}{l}\text { Valid } \\
\text { Percent }\end{array}$ & $\begin{array}{l}\text { Comulative } \\
\text { Percent }\end{array}$ \\
\hline CP & 89 & 89 & 89 & 89 \\
P & 5 & 5 & 5 & 94 \\
SP & 6 & 6 & 6 & 100 \\
\cline { 1 - 3 } Total & 100 & 100 & 100 & \\
\hline
\end{tabular}

\begin{tabular}{|l|l|l|l|l|}
\hline $\begin{array}{l}\text { Valid } \\
\text { x.3.p5 }\end{array}$ & Frequency & Percent & $\begin{array}{l}\text { Valid } \\
\text { Percent }\end{array}$ & $\begin{array}{l}\text { Comulative } \\
\text { Percent }\end{array}$ \\
\hline CP & 68 & 68 & 68 & 68 \\
P & 6 & 6 & 6 & 74 \\
SP & 26 & 26 & 26 & 100 \\
\cline { 1 - 3 } Total & 100 & 100 & 100 & \\
\hline
\end{tabular}

Gambaran mengenai kondisi pengetahuan yang mempengaruhi keputusan nasabah menggunakan Produk Bank Syariah Indonesia Kantor Cabang Muara Bulian, dimana faktor tersebut dapat menimbulkan pengaruh bagi nasabah dalam memilih Bank Syariah Indonesia Kantor Cabang Muara Bulian dari pada Bank Konvensional lainnya.

Dimana hasil yang didapat sangat sesuai dengan yang ada dilapangan. Ini dapat dilihat dari hasil kegiatan penelitian berupa penyebaran kuisioner sebagaimana dalam tabel berikut:

Tabel 7. Rekapitulasi Dan Tangggapan Responden Terhadap Faktor Pengetahuan

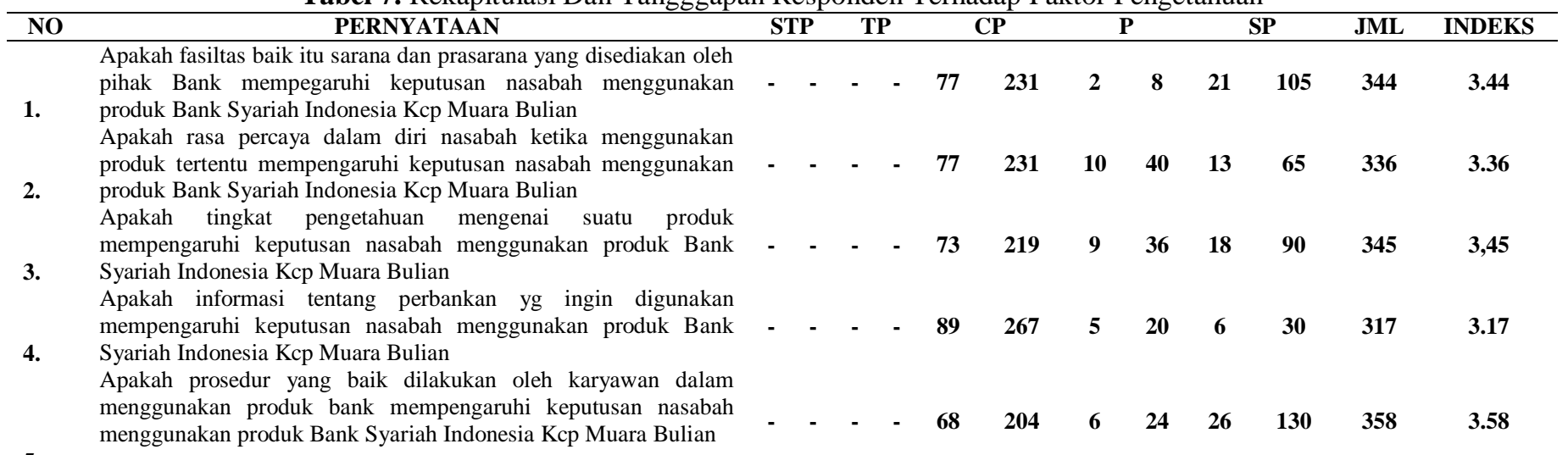


Sumantri, Diyah dan Albetris, Analisa Faktor-Faktor yang Mempengaruhi Keputusan Nasabah Menggunakan Produk Perbankan (Studi Kasus Nasabah Bank Syariah Indonesia Kantor Cabang Pembantu Muara Bulian)

Berdasarkan tabel 7 dapat diketahui hasil pengolahan dengan presentase dari lima aspek penilaian yang dinyatakan dalam tabel menunjukan hasil tertinggi adalah 3.58, yang terendah 3.17 dan rata-rata indeks dari 5 pernyataan di atas adalah 3.4 .

Berdasarkan dari hasil rata-rata indeks tabel di atas membuktikan bahwa faktor keputusan nasabah (pengetahuan) pada Bank Syariah Indonesia Kantor Cabang Muara Bulian berada pada kategori Cukup Baik.

\section{Faktor Lokasi}

Berdasarkan data dari SPSS.20, hasil yang di dapatkan yaitu Valid, karena sesuai dengan jumlah kuesioner yang telah disebar kepada nasabah Bank Syariah Indonesia Kantor Cabang Pembantu Muara Bulian. Dapat dilihat dalam tabel berikut:

Tabel 8. Data Kuesioner Nasabah Terhadap Faktor Lokasi, SPSS. 20

\begin{tabular}{|l|l|l|l|l|l|}
\hline Statistics & x.4.p1 & x.4.p2 & x.4.p3 & x.4.p3 & x.4.p4 \\
\hline Valid & 100 & 100 & 100 & 100 & 100 \\
Missing & 0 & 0 & 0 & 0 & 0 \\
\hline
\end{tabular}

\begin{tabular}{|l|l|l|l|l|}
\hline $\begin{array}{l}\text { Valid } \\
\text { x.4.p1 }\end{array}$ & Frequency & Percent & $\begin{array}{l}\text { Valid } \\
\text { Percent }\end{array}$ & $\begin{array}{l}\text { Comulative } \\
\text { Percent }\end{array}$ \\
\cline { 1 - 3 } CP & 27 & 27 & 27 & 27 \\
P & 52 & 52 & 52 & 79 \\
SP & 21 & 21 & 21 & 100 \\
\cline { 1 - 3 } Total & 100 & 100 & 100 & \\
\hline
\end{tabular}

\begin{tabular}{|l|l|l|l|l|}
\hline $\begin{array}{l}\text { Valid } \\
\text { x.4.p2 }\end{array}$ & Frequency & Percent & $\begin{array}{l}\text { Valid } \\
\text { Percent }\end{array}$ & $\begin{array}{l}\text { Comulative } \\
\text { Percent }\end{array}$ \\
\hline CP & 28 & 28 & 28 & 28 \\
P & 53 & 58 & 58 & 81 \\
\hline
\end{tabular}

\begin{tabular}{|l|l|l|l|l|}
\hline SP & 19 & 19 & 19 & \multirow{2}{*}{100} \\
\hline Total & 100 & 100 & 100 & \\
\hline
\end{tabular}

\begin{tabular}{|l|l|l|l|l|}
\hline $\begin{array}{l}\text { Valid } \\
\text { x.4.p3 }\end{array}$ & Frequency & Percent & $\begin{array}{l}\text { Valid } \\
\text { Percent }\end{array}$ & $\begin{array}{l}\text { Comulative } \\
\text { Percent }\end{array}$ \\
\hline CP & 49 & 49 & 49 & 49 \\
P & 5 & 5 & 5 & 54 \\
SP & 46 & 46 & 46 & 100 \\
\cline { 1 - 3 } Total & 100 & 100 & 100 & \\
\hline
\end{tabular}

\begin{tabular}{|l|l|l|l|l|}
\hline $\begin{array}{l}\text { Valid } \\
\text { x.3.p4 }\end{array}$ & Frequency & Percent & $\begin{array}{l}\text { Valid } \\
\text { Percent }\end{array}$ & $\begin{array}{l}\text { Comulative } \\
\text { Percent }\end{array}$ \\
\hline CP & 72 & 72 & 72 & 72 \\
P & 28 & 28 & 28 & 100 \\
\hline Total & 100 & 100 & 100 & \\
\hline
\end{tabular}

\begin{tabular}{|l|l|l|l|l|}
\hline $\begin{array}{l}\text { Valid } \\
\text { x.4.p5 }\end{array}$ & Frequency & Percent & $\begin{array}{l}\text { Valid } \\
\text { Percent }\end{array}$ & $\begin{array}{l}\text { Comulative } \\
\text { Percent }\end{array}$ \\
\hline CP & 23 & 23 & 23 & 23 \\
P & 16 & 16 & 16 & 39 \\
SP & 61 & 61 & 61 & 100 \\
\cline { 1 - 3 } Total & 100 & 100 & 100 & \\
\hline
\end{tabular}

Gambaran mengenai kondisi lokasi yang mempengaruhi keputusan nasabah menggunakan Produk Bank Syariah Indonesia Kantor Cabang Muara Bulian, dimana faktor tersebut dapat menimbulkan pengaruh bagi nasabah dalam memilih Bank Syariah Indonesia Kantor Cabang Muara Bulian dari pada Bank Konvensional lainnya.

Dimana hasil yang didapat sangat sesuai dengan yang ada dilapangan. Ini dapat dilihat dari hasil kegiatan penelitian berupa penyebaran kuisioner sebagaimana dalam tabel berikut:

Tabel 9. Rekapitulasi Dan Tangggapan Responden Terhadap Faktor Lokasi

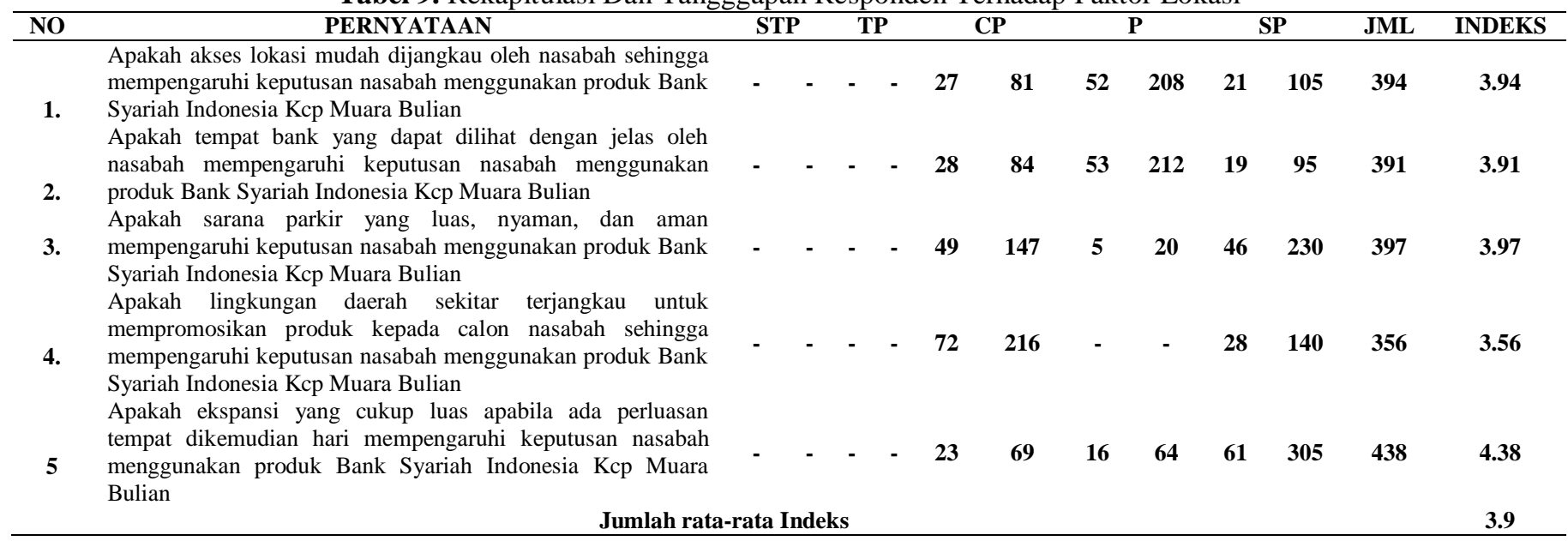

Sumber: Nasabah Bank Syariah Indonesia Kcp Muara Bulian(data diolah menggunakan IBM spss 20)

Berdasarkan tabel 9 dapat diketahui hasil pengolahan dengan presentase dari lima aspek penilaian yang dinyatakan dalam tabel menunjukan hasil tertinggi adalah 4.38, yang terendah 3.56 dan rata-rata indeks dari 5 pernyataan di atas adalah 3.9 .
Berdasarkan dari hasil rata-rata indeks tabel di atas membuktikan bahwa faktor keputusan nasabah (Lokasi) pada Bank Syariah Indonesia Kantor Cabang Pembantu Muara Bulian berada pada kategori Baik. 
Sumantri, Diyah dan Albetris, Analisa Faktor-Faktor yang Mempengaruhi Keputusan Nasabah Menggunakan Produk Perbankan (Studi Kasus Nasabah Bank Syariah Indonesia Kantor Cabang Pembantu Muara Bulian)

Faktor Dominan Yang Mempengaruhi Keputusan Nasabah Bank Syariah Indonesia Kantor Cabang Pembantu Muara Bulian.

Setelah melakukan penelitian terhadap nasabah pada Bank Syariah Indonesia Kantor Cabang Pembantu Muara Bulian dengan mengolah data yang di dapat dari penyebaran kuesioner maka didapat hasil rata-rata indeks dari masing faktor-faktor yang mempengaruhi keputusan nasabah. Dan hasil rekapitulasi rata-rata indeksnya adalah sebagai berikut :

Tabel 10. Rekapitulasi Hasil Rata-Rata Nilai Indeks Dari Faktor-Faktor Keputusan Nasabah

\begin{tabular}{llc}
\hline NO & $\begin{array}{l}\text { Faktor-Faktor Keputusan } \\
\text { Nasabah }\end{array}$ & Rata-Rata Indeks \\
\hline 1. & Pelayanan & 4.11 \\
2. & Karakteristik Bank & 4.87 \\
3. & Pengetahuan & 3.4 \\
4. & Lokasi & 3.9 \\
\hline
\end{tabular}

Sumber:Data diolah.

Setelah hasil pengolahan data yang di dapat dari penyebaran kuesioner kepada nasabah Bank Syariah Indonesia Kantor Cabang Pembantu Muara Bulian, dapat dilihat pada tabel 5.5. nilai rata-rata indeks dari tanggapan nasabah terhadap faktor-faktor yang mempengaruhi keputusan nasabah adalah sebagai berikut faktor Pelayanan memiliki nilai rata-rata indeks 4.11, faktor Karakteristik Bank memiliki nilai rata-rata indeks 4.87, faktor Pengetahuan memiliki nilai rata-rata indeks 3.4, dan faktor Lokasi memiliki nilai indeks dengan rata-rata 3.9. dilihat dari jumlah rata-rata nilai indeks dari masing-masing faktor keputusan nasabah di atas maka peneliti dapat menyimpulkan bahwa yang menjadi faktor dominan dalam mempengaruhi keputusan nasabah pada Bank Syariah Indonesia Kantor Cabang Pembantu Muara Bulian adalah faktor karakteristik bank, karena faktor karakteristik bank memiliki nilai rata-rata yang tertinggi sebesar 4.87 dari pada nilai ratarata indeks faktor-faktor keputusan nasabah lainnya.

\section{SIMPULAN}

\section{Tanggapan Nasabah Terhadap Faktor-Faktor Keputusan Nasabah}

Berdasarkan hasil penelitian dan pembahasan, maka beberapa pokok kesimpulan penelitian dapat dijelaskan sebagai berikut, faktor Pelayanan, Lokasi berada pada kategori Baik, faktor Karakteristik Bank berada pada kategori Sangat Baik, Pengetahuan berada pada kategori Cukup Baik.

\section{Faktor Dominan Yang Mempengaruhi Keputusan Nasabah}

Setelah hasil pengolahan data yang di dapat dari penyebaran kuisioner kepada nasabah Bank Syariah Indonesia Kantor Cabang Muara Bulian, dapat dlihat nilai rata-rata indeks dari tanggapan nasabah terhadap faktor-faktor yang mempengaruhi keputusan nasabah adalaah sebagai berikut faktor pelayanan memiliki nilai indeks 4.11, faktor Karakteristik Bank memiliki nilai indeks dengan rata-rata 4.87, faktor Pengetahuan memiliki nilai indeks dengan rata-rata 3.4, dan faktor Lokasi memiliki nilai indeks dengan rata-rata 3.9. dilihat dari jumlah rata-rata indeks dari masing-masing faktor keputusan nasabah di atas maka peneliti dapat menyimpulkan bahwa yang menjadi faktor dominan dalam mempengaruhi keputusan nasabah Bank Syariah Indonesia Kantor Cabang Pembantu Muara Bulian adalah faktor Karakteristik Bank, karena faktor Karakteristik Bank memiliki nilai rata-rata yang tertinggi dari nilai pada faktor keputusan nasabah lainnya.

\section{DAFTAR PUSTAKA}

Ahmadi, Adisetiawan, R., 2020, Multivariate Time Series in Macroeconomics, Eksis: Jurnal Ilmiah Ekonomi dan Bisnis, 2020, 11(2), 151-161

Asmas, D., Adisetiawan, R. 2019, Feedback: Stock Trading Activity, J-MAS (Jurnal Manajemen dan Sains), 4(1), 1-5

Arikunto, S. 2000. Prosedur Penelitian Suatu Pendekatan Praktek. Jakarta: Rineka Cipta.

Bambang Sunggono, 2005, Metode Penelitian Hukum, Jakarta, PT. Raja Grafindo Persada.

Drummond, Helga. 2007. "metode penelitian bisnis", edisi kelima, jilid 1. Erlangga. Jakarta.

Husein Umar. alat analisis data, Jakarta: 2001.

Mohammad Zubai Hippy, Analisis Faktor Yang Mempengaruhi Minat Menabung. Gorontalo: 2014.

Moleong, L.J. (2011). Metodologi Penelitian Kualitatif Edisi Revisi. Bandung: PT. Remaja Rosdakarya.

Sugiyono. 2011. Metode Penelitian Kuantitatif, Kualitatif dan $R \& D$. Bandung: Afabeta

Syafi'i Antonio. (2001). Bank Syariah . Jakarta: 2001.

Tjiptono, Fandy. (2002). Strategi Pemasaran. Yogyakarta : Penerbit Andi.

Undang-Undang Nomor 7 Tahun 1992 tentang Perbakan Undang-Undang No.10. (1998). Bank Syariah. Jakarta: 1998. 